\title{
SECURITY AND ETHICS IN SUSTAINABLE E-LEARNING AND GAMIFICATION FRAMEWORK FOR HIGHER EDUCATION
}

\author{
Aidrina Sofiadin \\ Faculty of Information and Communication Technology, International Islamic University Malaysia
}

\begin{abstract}
The world is moving towards achieving sustainable development goals that benefit the environment, society, and the economy. The COVID-19 pandemic has forced many education institutions to shift from traditional learning to online learning. Since 1960, e-learning has been delivering through the website. However, there is a rise in e-learning security and ethical issues that lead to poor education quality and an unsustainable e-learning system. Thus, security and ethics components need to be integrated into a sustainable e-learning and gamification framework. Interestingly, e-learning needs to integrate the gamification context to increase online learning quality and secure learners' education while promoting lifelong learning. To identify the relationship between security and ethics in gamified e-learning, this paper examined and assessed various types of security threads and learners' ethics and well-being in the e-learning environment. The framework intends to increase e-learning strength in promoting a better e-learning environment, well-being, and lifelong learning among their learners. Thus, enabling sustainable education through a reliable e-learning system.
\end{abstract}

\section{KEYWORDS}

e-Learning, Security, Ethics, Gamification, Sustainable Development, Sustainable Education

\section{INTRODUCTION}

Earlier before the pandemic, sustainable development goals (SDG) have become an interest by many countries to move toward a more equitable, prosperous, and resilient society. However, according to the Sustainable Development Goals 2020 report, Covid-19 threatens the progress to the SDG on healthy well-being, end of poverty, end of hunger, economic growth, access to water and sanitation, and environmental sustainability (United Nations, 2020). The fourth SDG, which aims to achieve inclusive and equitable access to education, is also be affected by the Covid-19. 
IADIS International Journal on WWW/Internet

The Covid-19 pandemic has pushed many higher education institutions (HEI) to shift to an online learning environment since social physical distance needs to be practiced. Many educational institutions were closed across the world and many learners are out of the classroom. Thus, the pandemic may change education forever due to the rise of online learning. Both academicians and learners are experiencing rapid changes in their education process as they need to transform their physical learning into digital platforms dramatically. Academicians are drastically working on developing online educational content. At the same time, learners are coping with their 'new normal' learning in a digital environment.

E-learning secures learners' education by allowing learners to continue to develop knowledge and skills via digital platform. Yet, learners' participation and engagement using e-learning seemed to be low without integrating interactive contents and game-based learning. Game technologies create opportunities for HEI to redesign and innovate their e-learning models to secure learners' education. security in e-learning

Since the pandemic has transform education into digital environment, online security is essential to avoid threats such as account breaches, Web attacks, data security, data center breaches, and access control. In order to protect e-learning against attacks like these, there is a need for a reliable learning management system. It is essential to identify the threats to e-learning so that the security risk analysis can be addressed. Also, there is a need for concerns on the learners' ethics in using e-learning. Cheating cases have risen in the online learning environment. Furthermore, since Covid-19 has led many students out of the classroom, learners' well-being has become an impact on the education quality.

\section{SECURITY IN E-LEARNING}

The concept of cybersecurity was introduced in 2008 which focuses on computer assets' integrity, confidentiality, and availability (Kaur and Ramkumar, 2021). Threats such as authentication, availability, confidentiality, integrity, and repudiation are increasing threats in e-learning platforms (Salimovna, Salimovna, and Ugli, 2019). In order to protect learners' authenticating credentials, security goals need to be identified. Policies, risk analysis, and training could increase e-learning security. Security policies that consider learners' home environment, technology usage, and instructor interaction need to be initiated and implemented.

Even though education is moving to the online environment, the dilemmas of learners' ethics, such as plagiarism and cheating in learning still occur in e-learning. The issue of cheating among learners is highly concerned among academicians. Bušíková and Melicheríková (2013) discovered that percentage of academic fraud has significantly increased in online programs. Many teachers have addressed the increase in cheating in online examinations. According to Wiley's recent survey, there are $93 \%$ of students suspect on cheating in online course. (Wiley,2020). Cases of unauthentic exams candidates have been experienced by many universities around the world. Since the students do not require to take attend physical examinations venue, they are paying an imposter to sat in for their online examinations and other assessments. The use of purchased assignments and sharing of answers were also has risen a new form of cheating. Thus, strict rules were established based on the e-learning environment due to such unethical practices among students. Wiley (2020) also suggested the implementation of monitor tests, integrate lockdown browser, use of webcams, and use plagiarism software to 
prevent cheating among learners. Risk analysis and training on e-learning could engage e-learning security and privacy.

According to the Academic Misconduct within Higher Education in Canada, the authors discovered a few main factors that drive learners to cheat (Hughes and McCabe, 2006). These factors include personal problems, the culture of cheating, unfair evaluation methods, and lack of explicitly between academic dishonesty and the way to manage it. Then in 2017, a United States research on e-learning integrity, values, and behaviors should be considered as part of an effective solution to solve academic cheating (Lee-Post and Hapke, 2017). This leads to the concerns of learners' well-being, such as academic honesty, mental health, physical health, and digital well-being. Wiley (2020) founds that many instructors believe that open-book exams may reduce learner's academic dishonesty. Almseidein and Mahasneh (2020) suggest that the learners should be aware of ethical issues to avoid these unethical behaviors.

Learners' well-being also is due to satisfaction with academic performance and experience. Some learners with a poor financial background and lack of e-learning facilities such as laptops and internet connection are experiencing education inequality. E-learning is able to promote equality and diversity by providing equal learning opportunities (Kentnor, 2015) to all types of learners. The use of technology in e-learning may lead to inequality (Gladieux and Swail, 1999) as it may lead to a digital divide among learners. Thus, the technology needs to be proficient among e-learning users and support by institutional infrastructure (Emil, 2001). On the other hand, education equity ensures that all learners are able to achieve the same learning outcomes, receive support on academic, social, and finance, and have access to adequate learning opportunities and educational resources (OECD, 2012).

\section{GAMIFICATION AND SUSTAINABILITY IN RECENT YEARS}

The use of gamification in e-learning also has a connection between learners' learning style, achievements, and behaviors (Zaric, Scepanovic, Vujicic, Ljucovic \& Davcev; 2017). Gamification in e-learning does have a positive impact on learners' engagement; however, one of the primary concerns with gamification elements is the inability to induce motivation among learners (Hassan, Habiba, Majeed \& Shoaib; 2019). Dale (2014) and Sailer and Homner (2019) found the combination of structural elements and social interaction among others were effective in fostering behavioral learning outcomes. The social interaction can be conducted by combining competition with collaboration among other learners, which can motivate the learner to learn.

There were several studies reported on gamification in higher education (Table 1). 
IADIS International Journal on WWW/Internet

Table 1. Studies on Gamification on Different Sustainability Context

\begin{tabular}{lccccc}
\hline Authors & Year & \multicolumn{4}{c}{ Sustainability Dimensions } \\
\cline { 3 - 6 } & & Strategies & Education & Consumption & Practice \\
\hline Lu and Ho & 2020 & $\mathrm{x}$ & & & \\
Mahmud et al. & 2020 & & $\mathrm{x}$ & $\mathrm{x}$ & \\
Romero-Rodriguez et al. & 2019 & & $\mathrm{x}$ & & $\mathrm{x}$ \\
Mattila & 2019 & $\mathrm{x}$ & $\mathrm{x}$ & & $\mathrm{x}$ \\
Schiele & 2018 & & & & $\mathrm{x}$ \\
Chui and Wai & 2017 & & & & \\
Nordby et al. & 2016 & & $\mathrm{x}$ & & \\
Polyak & 2016 & & $\mathrm{x}$ & & \\
Huber and Hilty & 2015 & & & $\mathrm{x}$ & \\
Hamari et al. & 2014 & & $\mathrm{x}$ & $\mathrm{x}$ & $\mathrm{x}$ \\
\hline
\end{tabular}

The outcomes of the studies reported in Table 1 show that gamification was mostly found to be positive influenced for the learners which the learners showed increased motivation, engagement, and enjoyment in their learning. The inclusion of gamification in e-learning promotes the quality of education that can increase learners' motivation, experience, and engagement and achieve greater learning success (Strmecki et al., 2015).

\subsection{Existing Studies on Gamification Framework}

In general, gamification is about designing game elements in a non-game context to promote user engagement (Susan, 2015), motivation (Roy \& Zaman, 2018), and satisfaction (Urh, Vukovic, Jereb \& Pintar, 2015). The key elements in gamification (Dale, 2014) are:

- Game mechanics - describes the use of elements such as points, badges and leader boards that are common to many games.

- Experience design - describes the journey players take with elements such as gameplay, play space, and storyline.

- Gamification - is a method to digitally engage rather than personally engage, meaning that players interact with computers, smartphones, wearable monitors, or other digital devices rather than engaging with a person.

- The goal of gamification - is to motivate people to change behaviors or develop skills, or drive innovation.

- Gamification focuses on enabling players to achieve their goals. When organizational goals are aligned with player goals, the organization achieves its goals because of players achieving their goals.

Palamino et al. (2019) separated the gamification framework in education into two; structural and content framework. Structural elements are focusing on game mechanics, and content elements are concentrating on the narrative concept. They found out that narrative characteristics have resembled user experience, which is important to influence engagement among learners. 


\section{SECURITY AND ETHICS IN SUSTAINABLE E-LEARNING AND GAMIFICATION}

FRAMEWORK FOR HIGHER EDUCATION

According to Majuri, Koivisto, and Hamari (2018), they found that based on the previous studies - behavioral outcomes were comprised of grades, participation in a system, and speed of conducting tasks and assignments. This is in line with the educational context which the aim is to achieve learning objectives that have been set by the organization (Dale, 2014). Figure 1 shows a summary of gamification elements in the e-learning context.

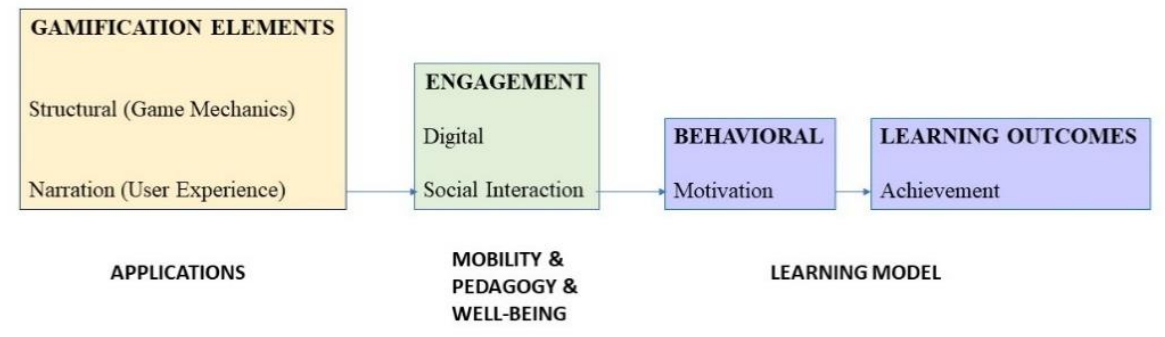

Figure 1. Studies on Gamification on Different Sustainability Context

\section{SUSTAINABLE E-LEARNING}

Sustainability is defined as a long-term innovation process that benefits the triple bottom line: people, environment, and economy (Foo, 2013). One of the sustainable development goals listed by the United Nations is quality education. In response to the pandemic, UNESCO launched the COVID-19 Global Education Alliance to ensure that learners can continue their studies. The Global Education Alliance aims to assist "countries in mobilizing resources and implementing innovation and Contextual solutions, using high-tech, low-end technology and non-technical methods to provide education remotely" (UN.org). This shows that from now on, education is maintained by providing "innovative and context-appropriate solutions." Through distance or e-learning platforms for learners to continue their studies in higher education institutions to avoid dropping out.

It is important to define sustainable e-learning because sustainable development has a wide range of meanings in different contexts. According to the research of Gunn (2010), e-learning is sustainable if 1) the online learning design is developed and implemented in the curriculum, and 2) other people can adopt the concept, design, system or resources of online learning, the sustainability of online learning can be realized and 3) the e-learning concept, design, maintenance and improvement of the system or resources are independent. Sustainable e-learning aims to ensure that the quality of education is maintained while minimizing costs and environmental impact (Sofiadin, 2013). In 2020, sustainable e-learning is defined as an e-learning system that ensures the development of learning goals and sustainable practice while supporting the dimension of sustainability (Sofiadin, 2020). 


\subsection{The Concept of Game-Based Learning in Sustainable e-Learning}

Game-based learning was introduced in the 1970s, which integrates games into a learning process to deliver certain skills and achieve certain learning objectives. Later in 2008, gamification was introduced which used game-like rule systems, entertainer skills, and characters for the gamification development (Su \& Cheng, 2013). Qian and Clark (2016) defined game-based learning as an environment in which game content and gameplay enhance learners' knowledge and skills acquisition. The game-based learning activities provide problem-solving spaces and challenges that provide learners with a sense of achievement. Wardoyo (2020) indicates that game-based learning able to increase learners' learning interest which creates a significant impact on the learning outcomes. Furthermore, game-based intends to promote learners' engagement (Bartel \& Hagel, 2014) and motivation (Zabala-Vargas et al., 2019) in higher education institutions, which will sustain online learning experience.

\subsection{Existing Sustainable E-Learning Framework}

There are various of existing e-learning frameworks that focused on e-learning quality, content, implementation, and governance (Georgouli et al., 2008; Yunus and Salim 2008; Chatti et al.2010; Alkhattabi et al.,2010; Sumranwong, 2011; Glancy and Isenberg, 2011; EPSA, 2011; Fang et al. 2012; Ramakrisnan et al. 2012; Hadullo et al. 2017). However, there is a few existing studies on sustainable e-learning framework.

In 2013, a sustainable e-learning framework was developed for higher education institutions in Malaysia (Sofiadin, 2013). The initial framework consists of four main categories that intend to support sustainability. These categories are:

a) Teaching and learning principle: refer to meeting the learner's education needs through lifelong learning.

b) Technology: focuses on the technology that will reduce, recycle, and reuse e-learning resources.

c) Application: This is related to the application that will promote mobility and learning personalization.

d) Sustainable development: refers to delivering sustainable education and a sustainable e-learning environment.

The sustainable e-learning framework will provide a good basis for the study to integrate the gamification approach in higher education, which it should be extended to include gamification dimensions that could promote lifelong learning and sustainable e-learning. The gamification in e-learning platform able to promote engagement among learners to continue learning and at the same time, to avoid drop-out or lessen other issues of conducting learning.

\section{METHODOLOGY}

Design thinking can be described as a development of artifacts (Simon, 1969) and meanings (Johansson and Woodilla, 2010). This study adopted the design thinking approach. This approach consists of five stages that involve understanding the users, problem-definition and problem-solving, brainstorming new ideas, developing prototypes, and testing (HSG, 2018; Lewrick et al., 2018). Design thinking promotes the innovation of new models that intend to 
improve and visualize creative processes conducted by multidisciplinary teams (Clemente et al., 2016). Thus, this study started by understanding the users' problems and generate new ideas through literature review. Literature research can be considered as a comprehensive summary of existing literature and could lead to a new framework developed for the specific area of study (Vom Brocke et al., 2009). As a result, this study proposed a framework for sustainable e-learning by adding the gamification aspect in the framework. However, this paper does not conduct the testing phase. The testing phase will provide results that rethinking one or more problems. The proposed framework will be tested and validated by e-learning stakeholders through surveys and online interviews and will be reported in another paper.

\section{THE PROPOSED SUSTAINABLE E-LEARNING AND GAMIFICATION FRAMEWORK}

Based on the literature review, there are a few criteria (see Table 2) that will assist the researchers in developing the initial sustainable e-learning and gamification framework for higher education. The initial framework (see Figure 2) represents the element in designing the framework, which needs to be focused on transforming education as part of surviving the pandemic. The components of the initial sustainable e-learning and gamification framework are shown in Table 2.

Table 2. Components of Gamification Sustainable E-Learning Framework

\begin{tabular}{llll}
\hline Key & Components & Description & References \\
\hline $\begin{array}{l}\text { Teaching and } \\
\text { Learning }\end{array}$ & Curriculum & The curriculum is intended to develop Doyle, \\
Principles & knowledge and skills among players 1978; & through online quizzes, assessments, and Udosen and \\
& learning activities. Play metrics can be Ekpo. 2016 \\
& captured to differentiate instruction and \\
& assessment that can be personalized to a \\
& learner. The gamified course curriculum \\
& should improve learner's engagement and \\
& enjoyment. A Teacher-centred curriculum \\
& defines learner ability through technique \\
& expertise, understanding of rules, and game \\
& participation. A learner-centered \\
curriculum is where the students will \\
determine what and how it is processed and \\
how it is learned. The curriculum should \\
focus on learning content design to a \\
learning experience that is motivating and \\
captivate to learners. \\
Pedagogy approaches include constructive, Nousiainen \\
collaborative, critical thinking, problem- et al. 2018; \\
solving, reflective, and inquiry-based Hanghøj \\
learning. Pedagogical knowledge practices 2013.; \\
such as project-based group work can be Becker.2009 \\
used as game-based teaching.
\end{tabular}


IADIS International Journal on WWW/Internet

Learning Model

Sustainable

Education

Artificial intelligence

Mobility

Game Engines

Levels

Virtual reality
Use of the Game Achievement Model that defines the learning objectives for the game and defines the storyline that will encompass these objectives. It should promote intrinsic motivation for the learners to play.

Provide interactive game-based learning that promotes sustainability literacy skills and sustainable practices.
Amory and Seagram.

2003

Cheah, Wei,

Kee, and Mohamad. 2013;

Emblen-

Perry. 2018.

Technology Simulation

Simulation is able to create students mental models of complex situations and their strategies in problem-solving.

Provide a safe environment to experiment with the curriculum concepts. Virtual reality intends to increase learner's satisfaction, enjoyment, creativity, audio, and graphics quality.

Gredler

2002

Rizzo et al.

2011;

Pallavicini

et al 2019;

Shelstad et

al. 2017

Artificial intelligence (AI) is used for various parts of the game and aspects of nonplayer characters. AI is applied in behavior modelling aspects such as situation analysis, target selection, resource allocation, learning, and simulated perception.

Smartphones offer more practical, easy access, and easy to carry anywhere. Mobile devices allow learners to play the mobile game anywhere at any time.

Tozour. 2002;

Prakash et al. 2009

Schmitz et al. 2012; Nuryanti, 2015;

Rojas-

Mancilla

et al. 2019

Provides a powerful utility that helps in game development such as player interaction, graphics, animation, artificial intelligence, modeling, and networking.

Points are the rewards that are collected Byl. 2013; based on what learners earned during gameplay when they achieve a certain goal. A level in a game represents a story chapter, a set of challenges, or a separate subdivision in a game environment. Levels refer to a reward for loyalty where players received gifts, privileges, and benefits.

Prakash

et al. 2009

Dale, 2014

Deterding, Khaled,

Navke, and

Dixon.

2011; Byl.

2013 


\section{SECURITY AND ETHICS IN SUSTAINABLE E-LEARNING AND GAMIFICATION}

FRAMEWORK FOR HIGHER EDUCATION

Badges can be earned through positive
effort that present recognition and status of
completed challenges.

Quests

Social network

Leaderboards

$$
\text { completed challenges. }
$$

A quest refers to the sub-tasks that need to be completed as part of the ultimate goal of the game.

The game should be designed for social interaction elements.

Based on the accumulated points, the game leaderboards will display a list of high scores in a game.
Antin and

Churchill

2011;

Deterding,

Khaled,

Navke, and

Dixon.

2011. Byl.

2013

Byl. 2013

Deterding,

Khaled,

Navke, and

Dixon.

2011; Byl.

2013

Deterding,

Khaled,

Navke, and

Dixon.

2011; Dale, 2014

User verification to protect user's privacy. Kang and

Kim (2015)

$\begin{array}{llll}\text { Security } & \text { Authentication } & \text { User verification to protect user's privacy. } & \text { Kang and } \\ & & \text { Onlime education activities and resources } & \text { Bernik et al., }\end{array}$
should be accessible and available.

(2017)

Use of digital tools such as Artificial Intelligence to detect misconduct and cheating.

Integrity

Identify the users' rights to privacy and data security.

Khan et al. (2021)

Schulz,

Isabwe, and

Reichert

(2015)

Game design should be intended for both males and females. Also, the game should be designed for players with cognitive disabilities. The game should be designed for a diversity of learners.

Illegal activity that leads to security threats that may impact other players.

User passion to learn for more skills, competition, social interaction, healthy lifestyle, and skill development.
Robles et al. 2008

Earp et al. (2018)

Kim and Werbach (2016) 
IADIS International Journal on WWW/Internet

Table 2 shows that gamification can be applied in all four key elements of the initial framework: Teaching and Learning Principles, Technology, Applications, and Security and ethics. These all four key elements require support not only from the management of higher education, but also from the lecturers, learners, and government. The implementation of sustainable e-learning and gamification is the innovative solution that intends to promote education equality among learners, lifelong learning, and lower the drop-out rates.

Table 3. The Key Elements Sustainable Dimensions

\begin{tabular}{ll}
\hline Key Element & Sustainable dimensions (supporting SDGs) \\
\hline Teaching and Learning Principles & SDG\#4. Quality education- to comprehensive and \\
& equitable to quality education \\
Technology & SDG\#4. Quality education- to ensure equitable access \\
& to quality education \\
& SDG\#5. Gender equality - learning games should be \\
designed for both men and women. & SDG\#9. Foster innovation - transform e-learning to \\
& game infrastructure. \\
& SDG\#10. Reduced inequalities - accessing e-learning \\
& through an interactive mobile game. \\
& SDG\#4. Quality education- promote lifelong learning \\
& through motivations \\
Applications & SDG\#3. Promote well-being - develop learning \\
& passion through interactive learning games. \\
\hline
\end{tabular}

To become sustainable, the key elements of the framework need to support the sustainable dimensions. In the paper, the key elements aim to support the SDGs (see Table 3). As shown in Table 3, the main SDG for this paper is on quality education. This is to ensure that e-learning provides comprehensive and equitable access to quality education through the gamification approach. Due to the COVID-19 pandemic, many learners have to experience stress and depression issues due to the lockdown and restricted movement. Therefore, this paper aims to improve learners' well-being by proposing interactive e-learning through gamification, which also intends to support SDG on promoting well-being. Since games were mostly designed for males, it should also be designed for females. Thus, this will support the SDG on gender equality. The SDG on foster innovation can be supported through the transformation of e-learning to game-based learning. Due to a number of learners who afford to own a smartphone than a desktop or a laptop, the idea of gamified e-learning intends to reduce inequalities by offering e-learning access through an interactive mobile game.

Table 4. Potential solutions for e-learning security

\begin{tabular}{|cl|}
\hline Security potential solutions & Descriptions \\
\hline Digital watermarking & $\begin{array}{l}\text { Add hidden copyright signs that protect multimedia database } \\
\text { servers against unauthorized use. }\end{array}$ \\
\hline Biometric authentication & Authentication techniques that are not easily stolen or copied. \\
\hline Cryptography & Convert data in a scramble format. \\
\hline Digital Rights management & Rights associated with intellectual property. \\
\hline Firewall & $\begin{array}{l}\text { Security software that protects network's servers and end-user } \\
\text { devices against security breach. } \\
\text { E-learning for all } \\
\text { Securing learners' education by providing e-learning that is } \\
\text { designed for all types of learners. }\end{array}$ \\
\hline
\end{tabular}


Table 5. Potential solutions for e-learning ethics

\begin{tabular}{|ll|}
\hline Ethics potential solutions & Descriptions \\
\hline Online training & $\begin{array}{l}\text { Promote ethical values and create awareness about the rules and } \\
\text { consequences of unethical behavior. }\end{array}$ \\
\hline Code of ethics & Ethical rules and policies in using the e-learning system. \\
\hline Digital well-being & $\begin{array}{l}\text { Digital platforms that deliver proactive care to learners to support } \\
\text { their mental health. }\end{array}$ \\
\hline
\end{tabular}

Security and ethics in e-learning system need to be addressed to ensure a sustainable e-learning. Table 4 and Table 5 above are a few solutions for e-learning security and ethics. Trainings or seminars could create awareness on security and ethics among learners. The consequences of legal issues such as preventive privacy, plagiarism, and copyright need to be realized. Academic honesty, mental health, and physical health can be improved through online training, clear e-learning ethics rules and policies, and digital well-being platforms. In conclusion, the initial framework (see Figure 2) shows the elements of designing the sustainable e-learning and gamification framework for higher education.

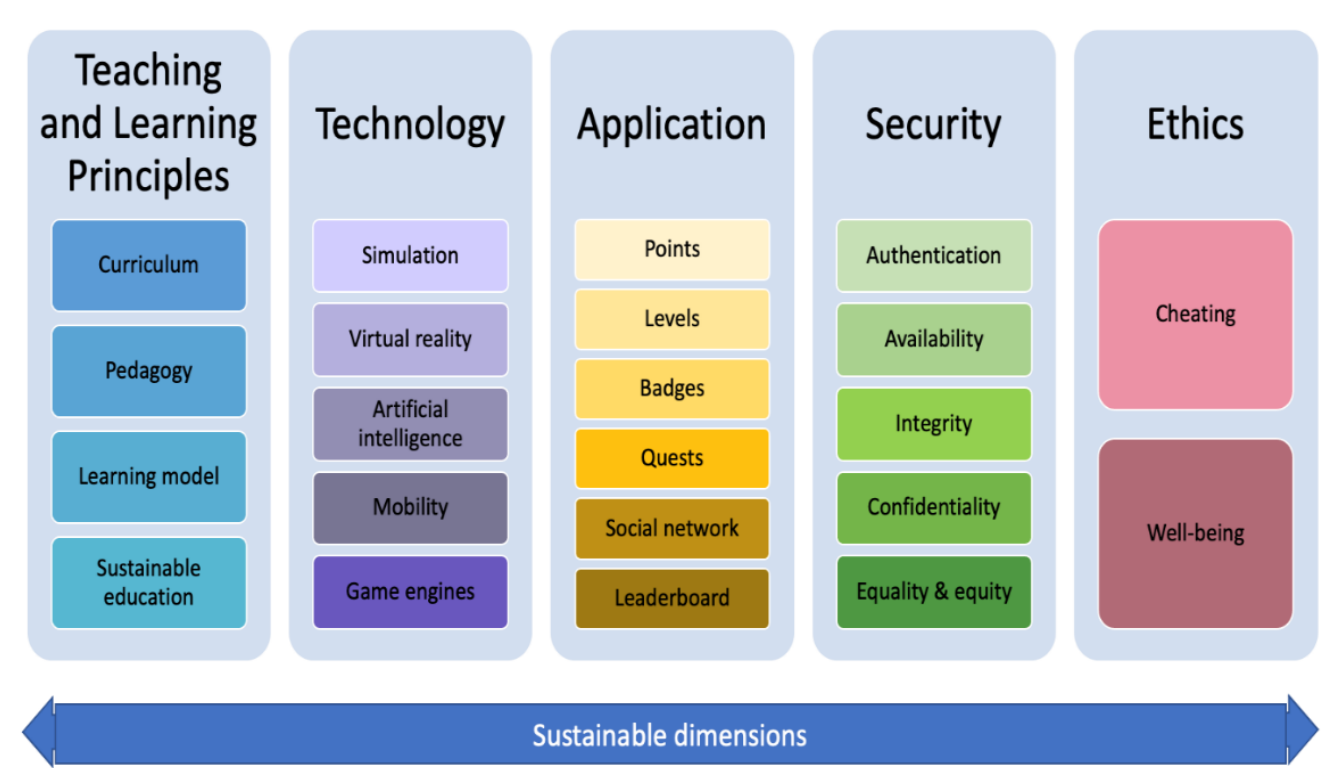

Figure 2. The Proposed Security and Ethics for Sustainable E-Learning and Gamification Framework

\section{CONCLUSION}

The paper presents gamification in e-learning platforms can increase learners' engagement and motivation during their learning process. The initial sustainable e-learning and gamification framework clarifies that gamification can be implemented in higher education institutions to sustain and provide quality education among learners, especially during the pandemic. In order for gamified e-learning to be operationalized in a real education setting, security and ethics 
IADIS International Journal on WWW/Internet

elements need to be measured to secure learners' education. Students should be aware of ethical and security issues to avoid unethical behavior. This can be done through training or seminars on awareness of ethics and security in e-learning. Thus, this study intends to provide guidelines and recommendations on how teaching and learning principles, technology, applications, security, and ethics can be used to achieve a sustainable gamified e-learning. In addition, the study intends to support SDGs on promoting well-being, gender equality, innovation, and inequality reduction. Based on the literature review, there is slight or no research on developing an initial sustainable e-learning and gamification framework that adopts security and ethics components. The framework should be further tested and validated by conducting the test stage of the design thinking approach to identify more problems that may lead to improvements. In conclusion, this research will work toward developing and evaluating a sustainable e-learning and gamification framework that will transform e-learning for the new norm.

\section{REFERENCES}

Alkhattabi, M., Neagu, D. and Cullen, A. 2010. Information Quality Framework for e-Learning Systems. Knowledge Management \& E-Learning: An International Journal, 2, pp. 340-361.

Almseidein, T.A., and Mahasneh, O.M.K. 2020. Awareness of Ethical Issues when using an e-Learning System. International Journal of Advanced Computer Science and Applications, Vol.11, No.1, pp. 128-131.

Amory, A. and Seagram. R. 2003. Educational game models: conceptualization and evaluation. South African Journal of Higher Education Vol.17(2), pp. 206 - 217.

Bartel, A., and Hagel, G. 2014. Engaging students with a mobile game-based learning system in university education. IEEE Global Engineering Education Conference (EDUCON), Global Engineering Education Conference (EDUCON), pp. 957-960.

Becker, K. 2009. Video Game Pedagogy: Good Games=good Pedagogy. In Games: Purpose and Potential in Education, edited by Christoper Thomas Miller, pp.73-125. New York: Springer.

Bekker, T., Sturm, J. and Barakova, E. 2010. Designing for social interaction through physical play. Personal and Ubiquitous Computing, Vol. 14(5), pp. 281-283.

Bernik, A., Radosevic, D., and Bubas, G. 2017. Introducing gamification into e-learning university courses. $40^{\text {th }}$ International Convention on Information and Communication Technology, Electronics and Microelectronics (MIPRO), 2017, pp. 711-716, doi: 10.23919/MIPRO.2017.7973515.

Bušíková, A. and Melicheríková, Z. 2013. Ethics in e-learning. IADIS International Conference e-Learning 2013. pp. 435-438.

Byl, P. 2013. Factors at Play in Tertiary Curriculum Gamification. International Journal of Game-based Learning. Vol. 3(2), pp. 1-21.

Cathy G.2010. Sustainability factors for e-learning initiatives. Journal Research in Learning Technology. Vol.18(2), 89-103.

Chatti, M. A., Agustiawan, M. R., Jarke, M. and Speeht, M. 2010. Toward a Personal Learning Environment Framework. International Journal of Virtual and Personal Learning Environments, Vol.1, pp. 66-85.

Cheah, W., Wei, T. Z., Kee, B. H., and Mohamad, F. S. 2013. Sustainability education for fun: An interactive mobile learning system. Proceedings of the International Conference on Informatics and Creative Multimedia. Kuala Lumpur, Malaysia. 


\section{SECURITY AND ETHICS IN SUSTAINABLE E-LEARNING AND GAMIFICATION}

FRAMEWORK FOR HIGHER EDUCATION

Clemente, V, Vieira, R and Tschimmel, K. 2016. A learning toolkit to promote creative and critical thinking in product design and development through Design Thinking. In: International Conference of the Portuguese Society for Engineering Education (CISPEE), Vila Real, pp. 1-6.

Dale, S. 2014. Gamification: Making work fun, or making fun of work? Business Information Review, Vol. 31(2), pp. 82-90

Design Thinking at HSG, http://dthsg.com/phases/, last accessed July 2018

Deterding, S., Khaled, R., Nacke, L. E., and Dixon, D. 2011. From Game Design Elements to Gamefulness: Defining Gamification. Proceedings of the 15th International Academic MindTrek., Tampere, Finland., pp.9-15.

Doyle, W. 1978. Paradigms for research on teacher effectiveness, in: L. Shulman (Ed.) Review of research in education, pp.163-198.

Earp, J. Persico, D., Dagnino, F. M., Passarelli, M., Manganello, F., and Pozzi, F. 2018. "Ethical Issues in Gaming: A Literature Review" Proceedings of the 12th European Conference on Games Based Learning. SKEMA Business School. France. Editor: Ciussi, M. pp.54-61.

Edulearning2 .2015. A brief history of gamification: part III - the definitions, online blog: http://edulearning2.blogspot.com/2014/03/a-brief- history-of-gamification-part.html, last accessed July 1,2015

EmblenPerry, K. 2017. Promoting Education for Sustainability through game-based learning: Using the Sustainable Strategies Game to improve students' knowledge and skills of sustainable business practices. In: Leal Filho W. (eds) Handbook of Sustainability Science and Research. World Sustainability Series. Springer, Cham., pp. 849-866.

Emil, B. 2001. Distance Learning, Access, and Opportunity: Equality and E-Quality. Metropolitan Universities, Vol.12(1), pp.19-27

EPSA.2012. EPSA Implementation Framework. In: (INTAN), I. T. A. N. (ed.). Malaysia.

Fang, L., Chow, S. H. and Soo, W. M. 2012. Framework for Evaluation Blended Learning in a University Public-Speaking Course in Singapore. Journal IGI Global Snippet.

Foo, K. Y. 2013. A vision on the role of environmental higher education contributing to the sustainable development in Malaysia. Journal of Cleaner Production, pp. 1-7.

Georgouli, K., Skalkidis, I. and Guerreiro, P. 2008. A Framework for Adopting LMS to Introduce e-Learning in a Traditional Course. Journal Educational Technology \& Society, Vol (11), pp. 227-240.

Gladieux, L. E., and Swail,W. S. 1999, The Virtual University \& Educational Opportunity:

Issues ofEquity and Access for the Next Generation.

Glancy, F. H. \& Isenberg, S. K. 2011. A conceptual e-learning framework. European, Mediterranean \& Middle Eastern Conference on Information Systems 2011. Athens, Greece.

Gredler, M. E. 2002. Educational Games And Simulations: A Technology In Search Of A (Research) Paradigm.

Hadullo, K., Oboko, R., and Omwenga, E. 2017. A model for evaluating e-learning systems quality in higher education in developing countries. International Journal of Education and Development using Information and Communication Technology (IJEDICT), Vol.13(2), pp. 185-204.

Hanghøj, T. 2013. Game-based teaching: Practices, roles, and pedagogies. In New Pedagogical Approaches in Game-enhanced Learning: Curriculum integration. IGI Global., pp.81-101.

Ho Su, C. and Hsue Cheng, C. 2013. A mobile game-based insect learning system for improving the learning achievements. IProcedia-Social and Behavioral Sciences, Vol.103, pp. 42-50.

Hudgesm J.M.C., and McCabe, D.L. 2006. Academic Misconduct within Higher Education in Canada. Vol.36(2), pp. 1-21. 
IADIS International Journal on WWW/Internet

Kang, B.H., and Kim, H. 2015. A Design of E-learning User Authentication System. International Journal of Security and its Applications. Vol. 99(1), pp.45-50.

Kaur,J. and Ramkumar, K.R. 2021. The recent threats in cyber security: A review. Journal of King Saud University- Computer and Information Sciences. https://doi.org/10.1016/j.jksuci.2021.01.018

Kentnor, H. 2015. Distance Education and the Evolution of Online Learning in the United States. University of Denver, Curriculum and Teaching Dialogue, Vol.17(1), pp. 21-34

Khan, Z.R., Dyer, J., Bjelobaba, S., Gomes, S.F., Dlabolova, D.H., Sivasubramaniam, S., Biju, S.M., Hysaj, A., and Harish, P. 2021. Initiating count down - gamification of academic integrity. Int J Educ Integrity, Vol.17 (6). https://doi.org/10.1007/s40979-020-00068-0

Lee-Post, A. \& Hapke, H (2017). Online learning integrity approaches: Current practices and future solutions, Online Learning 21(1),135-145. doi: 10.24059/olj.v21i1.843

Johansson, U. and Woodilla, J. 2010. How to avoid throwing the baby out with the bath-water. An ironic perspective on design thinking. European Group for Organization Stud-ies Colloquium, Lisbon, Portugal.

New Straits Times.2020. IIUM awarded 2020 Sustainability Institution of the Year Award https://www.nst.com.my/news/nation/2020/07/607086/iium-awarded-2020-sustainability-institutionyear-award. (accessed November 5, 2020)

Nousiainen, T., Marjaana, K. Jenni, R. and Mikko, V. 2018 Teacher competencies in game-based pedagogy. Teaching and Teacher Education Vol.74(2018). pp. 85-97.

Nuryanti, F.H.P. 2015. Mobile Game Effectiveness for Game Enthusiasts Who Have Little Spare Time to Play Games. Sisforma. Vol.2(1), pp.10-12.

OECD, 2012, Equity and Quality in Education: Supporting Disadvantaged Students and Schools, OECD Publishing. http://dx.doi.org/10.1787/9789264130852-en

Pallavicini, F., Pepe, A., and Minissi, M. E. 2019. Gaming in Virtual Reality: What Changes in Terms of Usability, Emotional Response and Sense of Presence Compared to Non-Immersive Video Games? Simulation \& Gaming. pp.1-24. Sage publisher.

Palomino, P.D., Toda, A. M., Oliveira W., Cristea, A. I. and Isotani, S. 2019 Narrative for Gamification in Education: Why Should you Care? 2019 IEEE 19th International Conference on Advanced Learning Technologies (ICALT), Brazil, 2019, pp. 97-99, doi: 10.1109/ICALT.2019.00035.

Prakash, E., Brindle, G., Jones, K., Zhou, S., Chaudhari, N. S., and Wong, K. 2009. Advances in Game Technology: Software, Models, and Intelligence. Simulation \& Gaming. Vol. 40(6), pp.752-801. Sage publisher.

Qian, M. and Clark, K.R.2016. Game-based learning and 21st century skills: a review of recent research. Journal Computers in Human Behavior, Vol.63, pp. 50-58.

Ramakrisnan, P., Yahya, Y., Hasrol, M. N. H. and Aziz, A. A. 2012. Blended Learning: A Suitable Framework For E- learning in Higher Education. Procedia Social and Behavioral Sciences, Vol. 67, pp. 513-526.

Rizzo., A., Lange, B., Sums, E.A., and Bolas, M. 2011. Virtual Reality and Interactive Digital Game Technology: New Tools to Address Obesity and Diabetes. Journal of Diabetes Science and Technology. Vol. 5(2), pp. 257-264.

Robles, R. J., Yeo, S., Moon, Y., Park, G., \& Kim, S. 2008. Online Games and Security Issues. Editors: Ahmad, D. \& Arce, I. Attack Trends. IEEE Security \& Privacy. pp. 76-79. IEEE Computer Society Publisher.

Rojas-Mancilla, E., Conei, D., Bernal, Y.A., Astudillo, D. and Contreras. Y. 2019. Learning Histology Through Game-Based Learning Supported by Mobile Technology. Int. J. Morhol. Vol. 37(3), pp .903-907. 


\section{SECURITY AND ETHICS IN SUSTAINABLE E-LEARNING AND GAMIFICATION}

FRAMEWORK FOR HIGHER EDUCATION

Roy, R. V., and Zaman, B.2018. Need-supporting gamification in education: An assessment of motivational effects over time, Computers \& Education,Vol.127(2018), pp.283-297.

Sailer, M and Homner, L. 2019. The Gamification of Learning: a Meta-analysis. Educational Psychology Review (2020) Vol, 32, pp.77-112

Salimovna, F.D., Salimovna, Y.N., and Ugli, I.S.Z. 2019. Security issues in E-learning system. 2019 International Conference on Information Science and Communications Technologies (ICISCT).

Sandusky, S. 2015. Gamification in Education. Educational Technology Graduate Papers. The University of Arizona.

Scepanovic, S. zaric, N. and Matijevic, T.2015. Gamification in higher education learning- state of the art - challenges and opportunities. Conference in e-Learning, Serbia.

Schmitz B., Klemke R., and Specht M. 2012. Mobile Gaming Patterns and Their Impact on Learning Outcomes: A Literature Review. Ravenscroft A., Lindstaedt S., Kloos C.D., Hernández-Leo D. (eds) 21st Century Learning for 21st Century Skills. EC-TEL 2012. Lecture Notes in Computer Science, Vol. 7563. Springer, Berlin, Heidelberg.

Schulz, R., Isabwe, and Reichert, F. 2015. Ethical issues of gamified ICT tools for higher education. 2015 IEEE Conference on e-Learning, e-Management and e-Services (IC3e). pp. 27-31, doi: 10.1109/IC3e.2015.7403481.

Shelstad, W.J., Smith, D.C., and Chaparro, B.S. 2017. Gaming on the Rift: Virtual Reality Affects Game User Satisfaction. Proceedings of the Human Factors and Ergonomics Society 2017 Annual Meeting. pp. 2072-2076.

Simon, H.1969. The Sciences of the Artificial, 1st eds, MIT Press, Cambridge, MA.

Smiderle, R., Rigo, S.J., Marques, L.B., Coelho, J.A.P.M., and Jaques, P.A. 2020. The impact of gamification on students' learning, engagement and behavior based on their personality traits. Smart Learning Environment, Vol. 7(3). https://doi.org/10.1186/s40561-019-0098-x

Sofiadin, A. 2020. Defining Sustainable e-learning: A meta-synthesis. Journal of Information Systems and Digital Technologies, Vol.2(2), pp. 72-84.

Sofiadin, A.2013. Development and Evaluation of a Sustainable E-Learning Framework for Higher Education Institutions in Malaysia. International Conference on Sustainability, Technology and Education.

Strmečki, D. Bernik, A. and Radošević, D.2015. Gamification in E-Learning: Introducing Gamified Design Elements into E-Learning Systems. Journal of Computer Sciences, Vol.11(12), pp. 1108-1117.

Sumranwong, D.2011. An eLearning Model Application for AS9100 Standard. 2011 International Conference on Information Management, Innovation Management and Industrial Engineering. Shenzhen, China.

Udosen, A.E. and Ekpo, U. S. 2016. Instructional Games: Implications for Curriculum and Instruction. Equatorial Journal of Education and Curriculum Studies. Vol. 1(1), pp. 24-42.

United Nations.2015. The post-2015 development agenda. United Nations Sustainable Development Summit 2015, 25-27 September 2015, New York, United States.

United Nations, 2020. The Sustainable Development Goals Report 2020. https://unstats.un.org/sdgs/report/2020/The-Sustainable-Development-Goals-Report-2020.pdf

Urh, M., Vukovic, G., Jereb, E., and Pintar, R. 2015. The model for introduction of gamification into e-learning in higher education. Procedia - Social and Behavioral Sciences 197. pp.388 - 397

Brocke, J.V., Simons, A. Niehaves, B., Riemer, K., Plattfaut, R., and Cleven, A. 2019 Reconstructing the Giant: On the Importance of Rigour in Documenting the Literature Search Process. Information systems in a globalising world: Challenges ethics and practices; ECIS 2009 17th European Conference on Information Systems. Italy. 
IADIS International Journal on WWW/Internet

Wardoyo, C., Satrio, D.Y. and Ma'ruf, D. 2020. Effectiveness of Game-Based Learning - Learning in Modern Education. 3rd International Research Conference on Economics and Business, KnE Social Sciences, Vol. 4(7), pp. 81-87.

Wiley, 2020. Academic Integrity in the Age of Online Learning: Survey Shows Sharp Rise In Instructor Perception of Cheating. https://www.wiley.com/network/instructors-students/covid-19-onlineteaching-resources-1/is-student-cheating-on-the-rise-how-you-can-discourage-it-in-your-classroom

Yunus, Y. and Salim, J.2008. Framework for the Evaluation of E-learning in Malaysian Public Sector from the pedagogical perspective. Information Technology. International Symposium, 2008. Universiti Kebangsaan Malaysia, pp. 1-8.

Zabala-vargas, S. A., Garcia-Mora, L. H., Ardila-Segovia, D. A.M, and Benito-Crosetti, B. L.2019. Motivation increase of mathematics students in Engineering - A proposal from Game Based Learning. 2019 International Symposium on Engineering Accreditation and Education (ICACIT), Engineering Accreditation and Education (ICACIT), pp. 1-6, (2019).

Zaric, N., Scepanovic, S., Vujicic, T., Ljucovic, J. and Davcev, D. 2017. The Model for Gamification of E-learning in Higher Education Based on Learning Styles. International Conference on ICT Innovations, pp. $265-273$. 